\title{
ENVIRONMENTAL FACTORS AND HUMAN PUBERTY
}

\author{
JP Bourguignon
}

Division of Paediatric and Adolescent Medicine, Department of Paediatrics, University of Liege, CHU SartTilman, B-4000, Liege, Belgium

Onset of puberty is thought to result from activation of the pituitary-gonadal system by the hypothalamic pulse generator, which drives the secretion of gonadotrophin-releasing hormone (GnRH). The age at which puberty starts can vary by 4-5 years between individuals (1). Such heterogeneity has fascinated generations of auxologists and endocrinologists. In addition to genetic factors, puberty is influenced by environmental factors, such as nutrition, photoperiod, temperature, physical activity, stress and intercurrent illnesses. The purpose of this short communication is to highlight the impact and mechanism of action of environmental factors on human puberty. More data on puberty are available for females than for males for several reasons, including the convenience of using menarche as a marker of puberty, the high sensitivity of the female axis to external cues and mobilizable energy, and the relatively more common occurrence of disorders of nutrition in adolescent girls.

\section{Environmental factors and puberty in an evolutionary perspective}

Throughout evolution, a trend has emerged to manage the environment so that reproductive capacity is no longer dependent on factors such as seasonality, the availability of food and reproductive behaviour. These environmental factors remain crucial throughout most of the animal kingdom and only man has succeeded in controlling the effect of the environment on puberty. Therefore, in man, the relative influence of genetic factors on the mechanism of puberty and reproduction has increased. It is my view that such genetic factors are linked to the prepubertal restraint of the pituitary-gonadal system. This inhibition shows increased potency and duration throughout evolution and may account for the long hiatus before puberty develops in man, compared with most animal species and primates (2).

\section{Environmental factors and puberty in a secular perspective}

Human development has tended to accelerate with increasing industrialization, and this has resulted in a secular trend in the earlier occurrence of menarche (3) and in an increase in adult height (4). It appears that these phenomena are now attaining a degree of stability in many countries, such as Japan (5). Recently, some authors have even suggested that the secular changes in age at menarche have now started to reverse (6). In many developing countries, both environmental and genetic factors can explain the relatively late and markedly variable age at onset of puberty, such as is seen in animals in their natural environment (Fig. 1a). In humans in 
industrialized countries, as well as in animals in a laboratory setting, the restraining effect of environmental factors has been markedly reduced (Fig. 1b). An acceleration of the tempo of maturation can be demonstrated by raising female rhesus monkeys in conditions of controlled photoperiod and temperature, compared with those raised in a natural environment (7). Thus, age at onset of puberty has decreased with improved socio-economic status, and less variation between individuals is seen (Fig. 1b). The remaining variations between individuals are likely to result from genetic aspects, including ethnic origin (8). It is remarkable that boys show an intrinsic tendency to enter puberty late, in contrast with the more common early onset of puberty seen in girls. Such a difference is also likely to involve genetic factors related to gender; however, these factors have not been elucidated fully.

\section{Figure 1.}

Environmental
factors

(a)
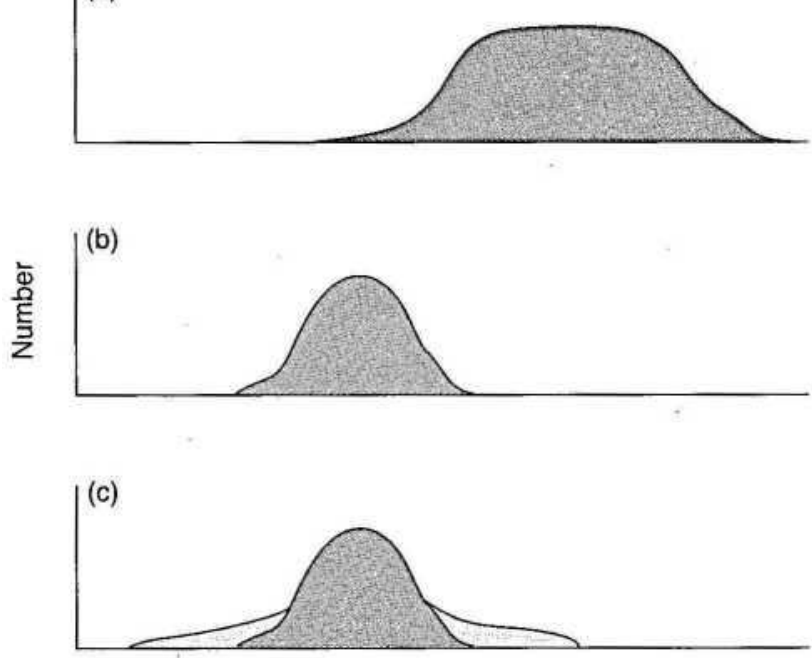

Age at onset of puberty

Schematic representation of the secular changes and milieu effect on variations in age at onset of puberty. The curves represent the distribution of age at onset of puberty, (a) Individuals from a developing country or animals in their natural environment. Both environmental factors and genetic factors are involved, (b) Individuals from an industrialized country or animals in a laboratory setting. Genetic factors are primarily involved in the physiological variations, (c) Individuals from a developed country with pathological disorders related to environmental factors.

The physiological role of environmental factors is rather limited in industrialized countries; however, these factors have an influence over some disorders of puberty (Fig. 1c). An obvious illustration is provided by the early onset of puberty seen in a number of adopted children (particularly in girls) from developing countries $(9,10)$. By contrast, a delayed onset of puberty can result from strenuous physical training such as that undertaken by gymnasts or ballet dancers, although such a situation may also involve emotional, nutritional and genetic factors (11-13). Changes in dietary habits, secondary to fear of obesity, can also delay sexual maturation (14). The pathophysiology of those conditions is complex, particularly concerning the implications for pubertal growth and adult height (15). 


\section{Mechanism of environmental effects on puberty}

In the early 1970s, Frisch and colleagues $(16,17)$ provided mathematical evidence that a critical ratio between fat and lean body mass had to be attained before the occurrence of menarche (fat, $22-24 \%$ of body weight) and a regular menstrual cycle (fat, $28 \%$ of body weight). Their concept was that fat mass could reflect, as a single parameter, the effects not only of dietary habits but also of secular changes, such as family size, altitude, physical training and other environmental aspects (17). Fat mass could, in turn, influence the neuroendocrine control of reproduction through changes in core temperature and oestrogen concentration or metabolism. On the basis of the recent discovery of leptin as a specific messenger from adipose tissue to the CNS (18), future studies on the possible role of such a protein on neuroendocrine systems may provide some answers. The hypothesis of Frisch has been challenged, however, by several studies indicating that regular menstrual cycles are observed in athletes with less than $17 \%$ body fat; a similar percentage of body fat is also seen in amenorrhoeic and eumenorrhoeic runners (19).

It appears that the role of the fat integrator may be played by the hypothalamus and the CNS, which are influenced by various environmental factors. The complexity of the mechanism is increased by the interactions between the different factors, such as eating and affective disorders in athletic amenorrhoea $(12,13)$.

Moreover, attention should always be paid to the genetic factors that may bias some observations, such as a delayed menarchal age in mothers of gymnasts (20). The study of environmental effects should not be restricted to age at menarche and regularity of the menstrual cycle. It has been reported recently that adiposity does not affect age at menarche, while duration of puberty is shorter in obese girls (21).

The mechanisms by which environmental factors produce an effect are complex. Emphasis has been placed on neuroendocrine changes, but peripheral effects on gonadal function cannot be excluded. In man, the most extensively studied mechanism is the pulsatile secretion of luteinizing hormone (LH), which mirrors hypothalamic GnRH secretion. The inhibitory effect of short-term fasting on pulsatile LH and sex-steroid secretion is well known; however, a reduction in LH pulse frequency has also been reported by some authors (22), while others have reported a reduction in LH secretion per pulse (23). Interestingly, a similar reduction in LH pulse amplitude has been observed in obese men (24). The neuromediators involved in such effects in man are still unknown and much information, is provided by animal research in this area (see Plant, this issue, pages 89-91).

\section{Conclusions}

In comparison with their ancestors on either a phylogenetic or a chronological basis, humans have evolved so that their reproductive capacity is less dependent on the environment. A physiological variation of 4-5 years in age at onset of puberty remains, which is predominantly determined by unspecified genetic factors. Environmental factors account for some pathological deviations of age at onset of puberty. 


\section{References}

1. Marshall WA. The relationship of puberty to other maturity indicators and body composition in man. J Reprod Fertil 1978;52: 437-43

2. Bogin B. Adolescence in evolutionary perspective. Acta Paediatr Suppl 1994;406: 29-35

3. Tanner JM. Growth and endocrinology of the adolescent. In: Gardner LI, editor. Endocrine and genetic diseases of childhood and adolescence. 2nd edn. Philadelphia: WB Saunders, 1975: 14-64

4. Van Wieringen JC. Secular growth changes. In: Falkner F, Tanner JM, editors. Human growth 2. Postnatal growth. New York: Plenum Press, 1978: 445-73

5. Takaishi M. Growth standards for Japanese children - an overview with special reference to secular change in growth. In: Hauspie R, Lindgren G, Falkner F, editors. Essays on auxology. Welwyn Garden City: Castlemead, 1995: 302-11

6. Dann TC, Roberts DF. Menarcheal age in University of Warwick young women. J Biosoc Sci 1993;25: 531-8

7. Wilson ME, Gordon TP, Rudman CG, Tanner JM. Effects of a natural versus artificial environment on the tempo of maturation in female rhesus monkeys. Endocrinology 1988;123: 2653-61

8. Eveleth PB. Population differences in growth: environmental and genetic factors. In: Falkner F, Tanner JM, editors. Human growth 3. Neurobiology and nutrition. New York: Plenum Press, 1979: 373-94

9. Proos LA, Hofvander Y, Tuvemo T. Menarcheal age and growth pattern of Indian girls adopted in Sweden. Acta Paediatr Scand 1991;80: 852-8

10. Bourguignon JP, Gerard A, Alvarez Gonzalez ML, Fawe L, Franchimont P. Effects of changes in nutritional conditions on timing of puberty: clinical evidence from adopted children and experimental studies in the male rat. Horm Res 1992;38 (Suppl 1): 97-105

11. Warren MP. The effects of exercise on pubertal progression and reproductive function in girls. J Clin Endocrinol Metab 1980;51: 1150-7

12. Theintz GE. Endocrine adaptation to intensive physical training during growth. Clin Endocrinol 1994;41: 267-72

13. Gadpaille WJ, Sanborn CF, Wagner WW. Athletic amenorrhea, major affective disorders, and eating disorders. Am J Psychiatry 1987;144: 939-42

14. Pugliese MT, Lifshitz F, Grad G, Fort P, Marks-Katz M. Fear of obesity. A cause of short stature and delayed puberty. N Engl J Med 1983;309: 513-18

15. Theintz GE, Howald H, Weiss U, Sizonenko PC. Evidence for a reduction of growth potential in adolescent female gymnasts. JPediatr 1993;122: 306-13

16. Frisch RE, Revelle R. Height and weight at menarche and a hypothesis of critical body weights and adolescent events. Science 1970;169: 397-9

17. Frisch RE. Body fat, puberty and fertility. Biol Rev Camb Philos Soc 1984;59: 161-88

18. Considine RV, Sinha MK, Heiman ML, Kriauciunas A, Stephens TW, Nyce MR, et al. Serum immunoreactive-leptin concentrations in normal-weight and obese humans. N Engl J Med 1996;334: 2925 
19. Sanborn CF, Albrecht BH, Wagner WW. Athletic amenorrhea: lack of association with body fat. Med Sci Sports Exerc 1987;19: 207-11

20. Theintz GE, Howald H, Allemann Y, Sizonenko PC. Growth and pubertal development of young female gymnasts and swimmers: a correlation with parental data. Int J Sports Med 1989;10: 87-91

21. De Ridder CM, Thijssen JHH. Bruning PF, Van den Brande JL, Zonderland ML, Erich WBM. Body fat mass, body fat distribution, and pubertal development: a longitudinal study of physical and hormonal sexual maturation of girls. J Clin Endocrinol Metab 1992;75: 442-6

22. Cameron JL, Weltzin TE, McConaha C, Helmreich DL, Kaye WH. Slowing of pulsatile luteinizing hormone secretion in men after forty-eight hours of fasting. J Clin Endocrinol Metab 1991;73: 35-41

23. Veldhuis JD, Iranmanesh A, Evans WS, Lizarralde G, Thomer MO, Vance ML. Amplitude suppression of the pulsatile mode of immunoradiometic luteinizing hormone release in fasting-induced hypoandrogenemia in normal men. J Clin Endocrinol Metab 1993;76: 587-93

24. Vermeulen A, Kaufman JM, Deslypere JP, Thomas G. Attenuated luteinizing hormone pulse amplitude but normal LH pulse frequency, and its relation to plasma androgens in hypogonadism of obese men. J Clin Endocrinol Metab 1993;76: 1140-6 